\title{
Towards Sustainable Innovation in the Bakery Sector-An Example of Fibre-Enriched Bread
}

\author{
Maria Królak ${ }^{1,+}{ }^{1}$, Hanna Górska-Warsewicz ${ }^{1, *}{ }^{\mathbb{D}}$, Magdalena Mądra-Sawicka ${ }^{2}$, Krystyna Rejman ${ }^{1} \mathbb{C}$, \\ Sylwia Żakowska-Biemans ${ }^{1}{ }^{\circledR}$, Julita Szlachciuk ${ }^{1}$, Maksymilian Czeczotko ${ }^{1}{ }^{1}$, Bartosz Kwiatkowski ${ }^{1}$, \\ Robert Zaremba ${ }^{1}$ and Michał Wojtaszek ${ }^{3}$
}

check for

updates

Citation: Królak, M.; Górska-Warsewicz,

H.; Mądra-Sawicka, M.; Rejman, K.;

Żakowska-Biemans, S.; Szlachciuk, J.;

Czeczotko, M.; Kwiatkowski, B.;

Zaremba, R.; Wojtaszek, M. Towards

Sustainable Innovation in the Bakery

Sector-An Example of Fibre-Enriched

Bread. Sustainability 2022, 14, 2743.

https://doi.org/10.3390/su14052743

Academic Editor: Flavio Boccia

Received: 27 December 2021

Accepted: 22 February 2022

Published: 25 February 2022

Publisher's Note: MDPI stays neutral with regard to jurisdictional claims in published maps and institutional affiliations.

Copyright: (C) 2022 by the authors. Licensee MDPI, Basel, Switzerland. This article is an open access article distributed under the terms and conditions of the Creative Commons Attribution (CC BY) license (https:// creativecommons.org/licenses/by/ $4.0 /)$.
1 Department of Food Market and Consumer Research, Institute of Human Nutrition Sciences, Warsaw University of Life Sciences-SGGW, 02-787 Warsaw, Poland; maria_krolak@sggw.pl (M.K.); krystyna_rejman@sggw.edu.pl (K.R.); sylwia_zakowska_biemans@sggw.edu.pl (S.Ż.-B.); julita_szlachciuk@sggw.edu.pl (J.S.); maksymilian_czeczotko@sggw.edu.pl (M.C.); bartosz_kwiatkowski@sggw.edu.pl (B.K.); robert_zaremba@sggw.edu.pl (R.Z.)

2 Department of Finance, Institute of Economics and Finance, Warsaw University of Life Sciences-SGGW, 02-787 Warsaw, Poland; magdalena_madra_sawicka@sggw.edu.pl

3 Faculty of Administration and Social Sciences, University of Economics and Innovation in Lublin, 20-209 Lubin, Poland; michal.wojtaszek@wsei.lublin.pl

* Correspondence: hanna_gorska_warsewicz@sggw.edu.pl

+ The author has passed away.

\begin{abstract}
This study aimed to examine the drivers and types of sustainable product innovations undertaken in bakeries with a particular focus on fibre-enriched bread. This type of bread contributes to a healthy diet due to its increased content of dietary fibre, which is an essential but deficient component of the diet, especially in modern consumption patterns in affluent countries. The study was carried out using the Computer Assisted Telephone Interview (CATI) method on a sample of 402 companies operating in the Polish baking industry. Multiple correspondence analysis (MCA) using Burt tables was used to analyse the results. Four groups of companies were identified according to the number of new products introduced to the market: non-innovative, poorly innovative, moderately innovative, and sustainable innovative companies. The results show that the development of a "new formula" was the most frequently mentioned type of innovation in all groups of companies. Other types of product innovation were also identified among the highly innovative companies: a new product for the company, a new product for the consumer, and new packaging. The basic motivation for launching innovative products on the market was to follow new trends and meet consumer expectations. Therefore, the results indicate that a consumer approach to innovation prevailed. The surveyed bakeries perceived fibre-enriched bread as a product with high nutritional value and environmental benefits. Our results contribute to a better understanding of the drivers of sustainable innovation in the food industry and have some practical implications for bakery companies seeking competitive drivers based on sustainable innovation. The study showed that capturing the voice of the customer is important in developing product innovations in bakeries. A consumer-oriented strategy is a win-win strategy, as it will result in an increased range of products suitable for a healthy sustainable diet and environmental benefits using fibre waste from food processing.
\end{abstract}

Keywords: bakery sector; sustainable innovation; fibre-enriched bread; company; multiple correspondence analysis

\section{Introduction}

The issue of sustainable innovation is becoming increasingly important in academic literature and business practice. This is because the ability of a company to create and implement innovations is considered to be one of the most important elements of their 
modernity, efficiency, and competitiveness [1-7]. It is related to innovation-based competitive strategy [8], the relationship between a company's innovativeness, and its business performance [9], as well as between innovation capabilities, technology platform, product platform, and performance $[5,6,9,10]$. The importance of sustainable innovation in the food industry should be further considered from a nutritional and environmental perspective [11,12]. This is particularly important in the development of products fortified or enriched with fibre and other functional ingredients, as they enhance the nutritional and health benefits of the diet, especially the expectations of health-oriented consumers $[13,14]$. The environmental benefits relate to the use of fibre, which can be obtained from food industry waste, particularly from the processing of fruit and vegetables [15-17].

In view of the above rationale, the purpose of the presented study was to examine the drivers and types of sustainable product innovation in bakeries in Poland, with a focus on fibre-enriched baked goods. The extension of the objective along with the research questions is presented in Section 1.4 (after the literature review).

\subsection{Definition of Sustainable Innovations}

Sustainable innovations are described in the context of classical innovations introduced to increase the profit of the company and to attract new customers for products or services in which the company specialises. In the scope of sustainable innovation, a wider range of activities leads to positive economic, social, and environmental transformation without compromising the needs and well-being of current and future generations. Therefore, sustainable innovation is defined as a process in which sustainability aspects (environmental, social, economic) are integrated into the company system and applied to products, services, technologies, and business models [18-20]. Sustainable innovation is often referred to as eco-innovation, changing production and consumption patterns and developing technologies, products, and services that reduce environmental impacts. As the economy grows, the environment is rapidly degrading, leading to a gradual decline in natural resources. Consequently, there is a demand for eco-innovations that reduce the negative human impact on the environment [18].

When defining sustainable innovation, it is also important to refer to the definition of innovation. There are many definitions of innovation in the literature that refer to the innovation processes in a company or indicate the characteristics of particular types of innovation [2-4,21]. Innovation can be seen as a deliberate and focused effort to achieve a change in the economic or social potential of an organisation [22]. It is also described as a "conscious decision-making process by which information (an idea) is transformed into an outcome be it tangible (product) or intangible (service)" [23], as well as process transforming ideas into outputs, which increase customer value [2]. It can also be seen as inventing new ideas and implementing them into new products or processes [24]. In general, innovation is a concept, product, process, or system that is perceived as new by an organisational unit [25]. Innovations are analysed by all activities related to creating an idea, creating an invention, and then implementing a new or improved product or process. This enables achieving a larger market share, gaining a competitive advantage, introducing new technological solutions, and benefiting with higher profitability and greater efficiency $[6,7,9,10,26-28]$. It can be considered in the context of a strategy incorporating competence building [29] and involving strategic resources [1,30-32], which is related to resource theory $[31,33,34]$.

\subsection{Types of Sustainable Innovation}

The types of sustainable innovation depend on the sustainable innovation strategies adopted. The literature on sustainable innovation strategies has identified seven key challenges in the economic, environmental, and social policy areas: (1) mitigating climate change and promoting cleaner energy; (2) ensuring that transport systems are environmentally sustainable and meet the economic and social needs of society; (3) promoting sustainable production and consumption patterns; (4) improving the management and prevention of overexploitation of natural resources; (5) promoting high-quality public 
health on a non-discriminatory basis; (6) creating an inclusive society, taking into account inter- and intra-generational solidarity and guaranteeing a high quality of life for citizens; and (7) actively promoting sustainable development internationally and ensuring that policies are consistent with the principles of sustainable development $[18,19]$.

Types of sustainable innovation should be referred to as types of innovation. A frequently cited classification of innovations indicates 5 types: (1) the introduction of a new product; (2) the introduction of a new method of production; (3) the opening of a new market; (4) the conquest of a new source of supply or raw materials or half-manufactured products; and (5) the carrying out of the new organisation of any industry [35]. This classification is reflected in world literature in theoretical considerations and practical application [36-39] and is also subject to numerous modifications [36,37,40-44]. Innovations shall be identified to the product, service, hybrid, technical, administrative, organisational structure, management, production, business system, and marketing [45]. Innovations can also be divided into two main groups: technological innovations i.e., new products, new services, new procedures, new policies, and administrative managerial innovations, i.e., new organisational forms, encourage expansions, reward staff's creativity, and methods for achieving corporate goals $[3,28]$.

For the statistics of national economies, Eurostat, and OECD countries, the classification of innovation developed in the "Oslo Manual" [46] is used. The Manual sets international standards for the conceptualisation and measurement of innovation. Four types of innovation have been identified: product innovation, process innovation, marketing innovation, and organisational innovation. Product innovations mainly concern the launch of a new or improved product, process innovations refer to the introduction of new or improved manufacturing systems, and organisational innovations concern changes in the functioning of the organisation [46].

\subsection{Innovations in the Food Industry}

Innovation in the food industry usually refers to technical and technological approaches in food production and the introduction of novel food [47,48]. In the scientific literature, three major food innovation trends are identified: sustainable food production and sustainable products, healthy food, and convenience food [49]. Mintel (one of the world's leading market intelligence agencies) also distinguishes three main directions of change and innovation in its "Global Food and Drink Trends 2030" forecast: improving the health of the planet and its population, enabling consumers to develop hyper-individualised approaches to physical and mental health through IT, and strengthening food science and technology as vital tools to ensure food supply [50]. Food producers are involved in new product development activities and market nutrient-enriched products or produced with the use of new technologies to meet consumer needs and demands and to be competitive in the marketplace [12,51].

Grains are a good source of dietary fibre. The basic raw materials in the Polish baking industry, i.e., wheat and rye, contain 11.5 and $12.9 \mathrm{~g}$ of fibre in $100 \mathrm{~g}$, respectively, but the most popular types of bread are made with refined cereal grain flour and therefore only contain 3-4 g of fibre. In human nutrition, dietary fibre is an essential component of a healthy diet as it controls blood cholesterol levels and reduces the risk of cardiovascular diseases, heart disease, stroke, obesity, type 2 diabetes, and various gastrointestinal disorders [52-54]. However, its intake in highly developed countries is far too low and below the recommended level $[55,56]$. Fortifying and enriching selected foods with dietary fibre seems to be a good solution to this problem. By-products from the processing of fruit, vegetables, pulses, and seeds are among the good sources of fibre [15-17]. Innovation to reduce food waste is one of the lines of action towards a future-proof food system that produces healthy and sustainable food for present and future generations [15-17,57].

The development of new food products fortified or enriched with fibre and other functional ingredients offers an opportunity to meet the expectations of health-oriented consumers. They are looking for new products with nutritionally value-added ingredients 
that promote health and wellness [11,12] and support the environment [58]. Such innovations, concerning the use of fibre in the bakery sector, were discussed in the examples of bread [13,14], cakes [15], muffins [59,60], and snacks [61]. If enrichment with dietary fibre or other functional ingredients concerns frequently consumed foods, such as white bread, health benefits can be achieved [62,63], even at the population level.

\subsection{Aim and Scope of Research}

Based on the literature review and the arguments presented above, our research aimed to examine the drivers and types of product-related sustainable product innovations in bakeries in Poland, with a focus on fibre-enriched bakery products. This is the next stage of a research project on bio-based products and innovative technologies for health-promoting bakery and pasta products with reduced calories, entitled "Bioproducts, innovative technologies of pro-health bakery products and pasta with reduced caloric value", within the task "Analysis of the market for cereal products to develop concepts for innovative products, considering the perspective of their producers to determine the conditions of operation and increasing the competitiveness of these enterprises". So far, the publications showing the results of this project referred to the acceptance of food technologies, perceived values and consumer expectations towards bread [51], the perception of dietary fibre as a part of nutritional knowledge affecting the consumption of fibre-rich bread [64], and the choice of bread in the background of the association between consumer awareness of dietary fibre and declared intention to eat [65]. This time, we looked at innovation from the perspective of manufacturers. There is a lack of literature on the innovativeness of bakery businesses and their ability to develop new products that are important from a nutritional point of view.

Thus, we formulated five research questions:

1. What is the intensity of product innovation activity in bakeries?

2. What types of innovations are being introduced in bakeries?

3. What factors determine the introduction of product innovation in bakeries?

4. How do bakeries perceive sustainable innovation on the example of bread enriched with fibre?

5. What are the drivers for bringing sustainable innovations to market using the example of fibre-enriched bread?

\section{Materials and Methods}

\subsection{Sample Selection}

The research was carried out using the Computer-Assisted Telephone Interview (CATI) method by a professional market research agency in two stages. The first stage was a pilot study to test the questionnaire on a sample of 40 companies operating in the bakery sector. In the second stage, we used the list of all companies registered in the bakery sector, available in the official REGON (National Official Register of Business Units) register kept by the national statistical office Statistics Poland. The research agency made the selection considering the location, i.e., administrative regions and the size of the company. According to Polish law (the Act of 6 March 2018), the size of a company is measured by the number of its employees and the sum of assets or the value of annual net turnover and determines the division of companies into micro, small, and medium enterprises. The administration of the survey from the technical side and sampling was on the side of the research agency, while a person from our team was responsible for methodological issues. The request to participate in the study was addressed to 2000 bakeries, of which 402 confirmations were received. The obtained sample meets the condition of proportionality in terms of the size of companies and their location in provinces (administrative regions in Poland) (Table 1). 
Table 1. Sample of companies according to size and location.

\begin{tabular}{|c|c|c|c|}
\hline Variable & No of Companies & & Share of Companies (\%) \\
\hline Total & 402 & & 100.0 \\
\hline \multirow{4}{*}{ Size of enterprise } & Micro-enterprise $^{1 /}$ & 120 & 29.9 \\
\hline & Small enterprise $2 /$ & 120 & 29.9 \\
\hline & Medium enterprise $^{3 /}$ & 81 & 20.1 \\
\hline & Large enterprise & 81 & 20.1 \\
\hline \multirow{16}{*}{ Province } & Dolnośląskie & 34 & 8.5 \\
\hline & Kujawsko -pomorskie & 20 & 5.0 \\
\hline & Łódzkie & 26 & 6.5 \\
\hline & Lubelskie & 24 & 6.0 \\
\hline & Lubuskie & 10 & 2.5 \\
\hline & Małopolskie & 34 & 8.5 \\
\hline & Mazowieckie & 44 & 10.9 \\
\hline & Opolskie & 14 & 3.5 \\
\hline & Podkarpackie & 20 & 5.0 \\
\hline & Podlaskie & 10 & 2.5 \\
\hline & Pomorskie & 22 & 5.5 \\
\hline & Śląskie & 56 & 13.9 \\
\hline & Świętokrzyskie & 18 & 4.5 \\
\hline & Warmińsko-mazurskie & 14 & 3.5 \\
\hline & Wielkopolskie & 36 & 9.0 \\
\hline & Zachodniopomorskie & 20 & 5.0 \\
\hline
\end{tabular}

1/ A micro-company: in at least one of the last two financial years employed on average less than 10 employees a year and achieved an annual net turnover from the sale of goods, products, and services as well as financial operations not exceeding the PLN equivalent of EUR 2 million, or the sum of the balance sheet assets prepared at the end of one of these years did not exceed the PLN equivalent of EUR 2 million. ${ }^{2 /}$ A small company: in at least one of the last two financial years employed an average of fewer than 50 employees per year and achieved an annual net turnover from the sale of goods, products, and services, as well as financial operations not exceeding the PLN equivalent of EUR 10 million, or the sum of assets of its balance sheet prepared at the end of one of these years did not exceed the PLN equivalent of EUR 10 million. ${ }^{3 /}$ A medium-sized company: in at least one of the last two financial years, employed an average of fewer than 250 employees on an annual basis and achieved an annual net turnover from the sale of goods, products, and services, as well as financial operations not exceeding the equivalent in PLN 50 million or total assets of its balance sheet prepared at the end of one of these years did not exceed the PLN equivalent of EUR 43 million.

A new product launch in the year preceding the survey was used as the recruitment variable. A new product was considered a product innovation, understood as the creation and then the launch of a new or improved product compared to the previous versions, which means a modification of the product, its composition, and/or production process.

The research was conducted following the ethical principles relating to a company understood by Article 551 of the Civil Code [66]. Respondents from individual companies were involved in product development tasks and included managers, technologists, sales, and marketing staff.

\subsection{Research Tool}

This study focuses on the data obtained from the three parts of the standardised questionnaire used in the project (Table 2), which concerned assortment analysis and product differentiation (part 1), types of innovation, and reasons for bringing them to the market (part 2), and fibre-enriched bread in terms of its perception and the factors involved in undertaking such an innovation (part 6). 
Table 2. Questionnaire structure.

\section{Questions}

Part 1. Assortment analysis and product differentiation
Answers

Number of products in the offer Number of new products being launched

New formula

New product for the company

New product for the consumer

New packaging

Types of innovations

New product on the market

Change in production technology

Increasing the product weight

Reducing the product weight

New trends on the market

Consumer expectations

Introduction of new products by the competitors

Change of assortment

Requirements of retailers

Opinion of the marketing department

Following foreign companies' decisions

Financial reasons

Patent purchase

Part 3. Innovation process

Part 4. Features of innovative bakery products

Part 5. Factors determining food product development

Perception

Higher nutritional value compared to other types of bread

Production in an environmentally friendly manner More caloric compared to other types of bread Extended shelf life

Part 6. Fibre-enriched bread

Factors influencing the decision to undertake such an innovation
Raw materials supply

Changes in production technology

Changes in sales organisation

Changes in consumer awareness

Changes in marketing activities

Changes in product quality

Other

\subsection{Statistical Analysis}

Data were analysed using descriptive statistics and multiple correspondence analyses (MCA) based on the Burt tables that average estimated and weigh the relative frequencies. The Burt table is a symmetric categories-by-categories matrix formed from contingency tables of variables $[67,68]$. MCA is a simple correspondence analysis that creates a matrix with cases as rows and categories as a variable in columns [69-72]. The MCA allows analysis of the pattern of relationships of several categorical dependent variables [67] by involving a multiway contingency table [70].

In the two-dimensional study, a solution was applied. This approach provides information on what categories of variables will be in two-dimensional graphics [73]. The MCA uses a matrix of indicator $(X)$ with $\mathrm{L}$-as a level of vector for nominal values-and $\mathrm{N}$ as several investigated observations (companies answers). The matrix is $\mathrm{L} \times \mathrm{N}$, where the level of a factor is $\Sigma \mathrm{Lk}=\mathrm{L}$ ( $\mathrm{k}$ - the number of observed variables). Each dimension was investigated according to inertia and eigenvalue measures.

\subsection{Profile of Companies Participating in the Study}

The characteristics of the surveyed companies are presented in Table 3. More than half of them $(54 \%)$ operated on the local market, defined by the city in the province. One in three 
(36\%) operated on a regional market. Less than $10 \%$ of the surveyed companies operated on the domestic market concerned, and 4 companies (1\%) operated on the international market. Most companies (almost 2/3) have been operating on the market for more than 15 years. The companies operating for the shortest time (less than 5 years), mainly bakeries, were in new housing estates and adapted their offer to the needs of residents and the immediate surroundings, focusing on the production of a diverse assortment. Almost 15\% of the bakeries participating in the survey conducted business activities for up to 9 years and $35 \%$ for up to 15 years. The largest percentage of enterprises, the vast majority (84\%), had a production department. More than a half of them declared the functioning of supply and administration departments, and almost a half of the sales department. In the context of the issue under consideration, it is worth noting that only $12 \%$ of companies had an R\&D (research and development) department in their structure.

Table 3. Sample characteristics.

\begin{tabular}{ccc}
\hline Specification & Number of Companies & Percentage \\
\hline Local & Area of activity (market) & \\
Regional & 218 & $54.2 \%$ \\
Domestic (whole country) & 143 & $35.6 \%$ \\
International & 37 & $9.2 \%$ \\
& 4 & $1.0 \%$ \\
\hline Less than 5 & Years of business activity & \\
5-9 & 11 & $2.7 \%$ \\
$10-15$ & 47 & $11.7 \%$ \\
More than 15 & 84 & $20.9 \%$ \\
& 260 & $64.7 \%$ \\
\hline Marketing & Company's departments & $22.1 \%$ \\
Sales / distribution & 89 & $48.3 \%$ \\
Communication & 194 & $19.2 \%$ \\
Research \& Development & 77 & $11.7 \%$ \\
Production & 47 & $84.3 \%$ \\
Delivery/supply & 339 & $53.5 \%$ \\
Quality control & 215 & $28.6 \%$ \\
Administration & 115 & $51.5 \%$ \\
Other i.e., human resources & 207 & $2.0 \%$ \\
\hline Total number & 8 & $100.0 \%$ \\
\hline
\end{tabular}

\section{Results}

\subsection{Intensity of Innovative Activity in Bakeries}

The studied bakeries were divided into groups according to the intensity of their innovation activities. The number of new products introduced to the market and expressed as a percentage of total products was used as a measure. First, the sample was split into two groups, i.e., companies that had not introduced any new product (91 companies, $22.6 \%$ of the total sample) and companies that had introduced new bakery products ( 311 companies, $77.4 \%$ ). The group that did not launch any new product in the year preceding the survey was defined as Group 1-non-innovative.

The companies that introduced new products to the market were divided into three groups using the quartile method (Figure 1): 
- Group 2: poorly innovative companies-78 companies, i.e., $25 \%$ of innovative companies, in which the share of new products in the total product range is the lowest (from $1.32 \%$ to $5.81 \%$ ).

- Group 3: moderately innovative companies-155 companies, i.e., $50 \%$ of innovative companies, in which the share of new products in the total product range is medium (5.82\% to $16.07 \%)$.

- Group 4: highly innovative companies-78 companies, i.e., $25 \%$ of innovative companies, in which the share of new products in the total product range is the highest $(16.08 \%$ to $69.57 \%)$.

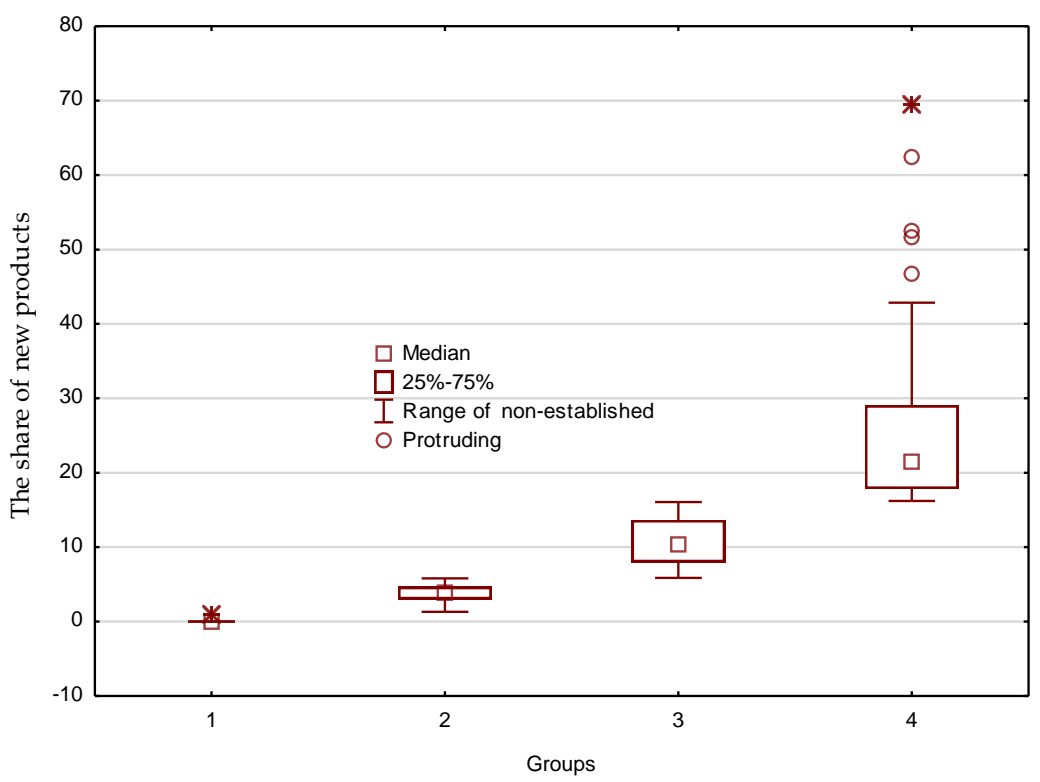

Figure 1. Bbox and whisker plot for groups of bakeries created in terms of intensity of innovative activity. Groups of bakeries: 1-non-innovative, 2-poorly innovative, 3-moderately innovative, 4-highly innovative.

\subsection{Types of Product Innovations}

Figure 2 presents the types of product innovations launched by companies. The most frequently mentioned type of innovation was the development of a 'new formula'. This applied to all three groups of companies introducing new products to the market in the year preceding the survey, with more than half of the companies in each group. Among highly innovative companies, another three types of product innovation have been declared by about $40 \%$ of companies. They were a new product for the company, a new product for the consumer, and new packaging.

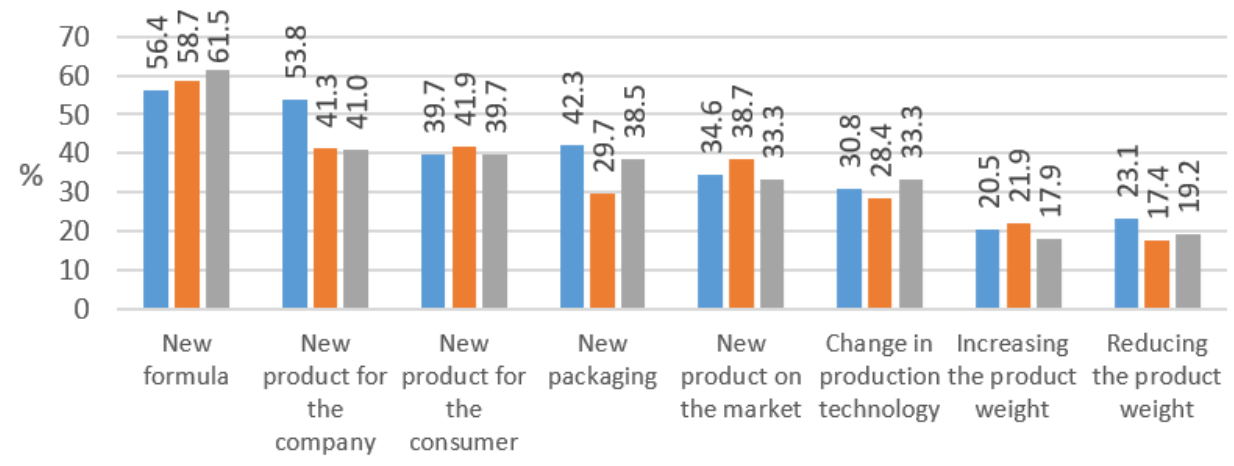

- poorly innovative moderately innovative $\quad$ mighly innovative

Figure 2. Type of product innovation in bakeries (\% of responses). 
In the next three paces, companies in group 2 (moderately innovative) indicated the following types of innovation: a new product for the consumer, a new product for the company, and a new product on the market. In turn, for companies with the lowest degree of innovation, the second most frequently introduced type of innovation was a new product for the company, followed by new packaging and a new product for the consumer. In the MCA of product innovation motives, two main groups were distinguished. The MCA in Figure 3 and Table 4 illustrates $32.68 \%$ of all inertia (total value of $\mathrm{Chi}^{2}$ statistics $=661.045$ when $p>0.05$ and table $22 \times 22$ ).

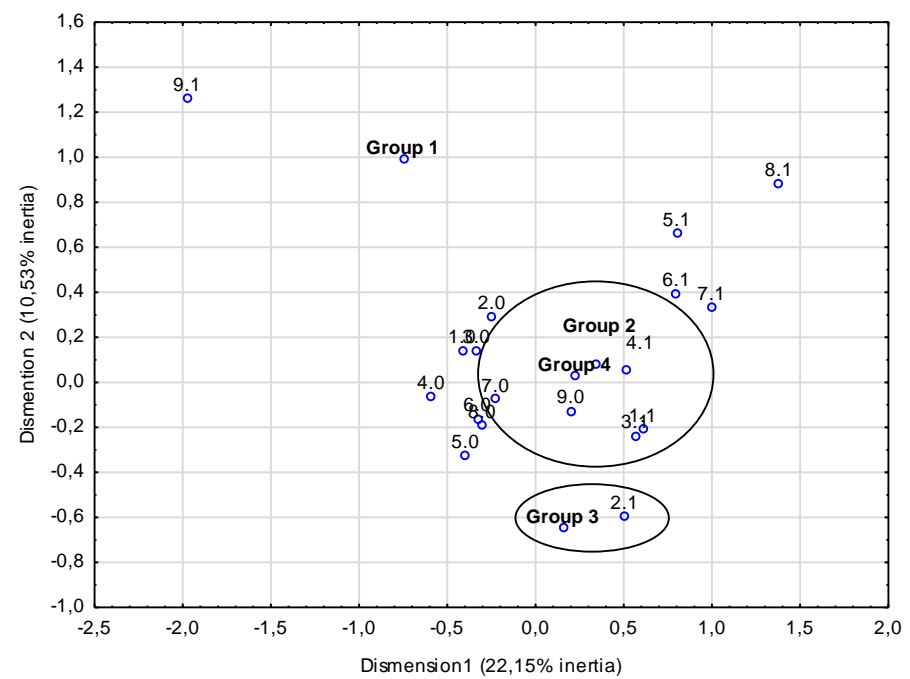

Figure 3. Types of product innovation in bakeries according to MCA results.

Table 4. Explain of the Figure 3.

\begin{tabular}{cc}
\hline Code & Types of Product Innovations \\
\hline $1 . X^{*}$ & New product for the company \\
$2 . X^{*}$ & New product on the market \\
$3 . X^{*}$ & New product for the consumer \\
$4 . X^{*}$ & New formula \\
$5 . X^{*}$ & New packaging \\
$6 . X^{*}$ & Change in production technology \\
$7 . X^{*}$ & Increasing the product weight \\
$8 . X^{*}$ & Reducing the product weight \\
$9 . X^{*}$ & Other \\
\hline${ }^{*} 0$ when it does not occur in a company and 1 when it does occur.
\end{tabular}

Companies in groups 2 and 4 were indicated by similar dimensional factors, such as a new formula (4.1), a new product for the company (1.1), and a new product for the consumer (3.1), and were not indicated by increased product weight (7.0) or other factors (9.0). Group 3 was described by one determinant, which was a new product on the market (2.1). No characteristic explained Group 1 (non-innovative companies).

\subsection{Factors Influencing Product Innovation in Bakeries}

Following new market trends and meeting consumers' expectations were the main factors determining the introduction of product innovations (Figure 4). The new market trends were the most important factor for the group of highly innovative companies (Group 4), as was indicated by $57.7 \%$ of them. Consumer expectations were the most important factor for poorly innovative companies (Group 2) since such declarations came from $60.3 \%$ of the companies in this group. 


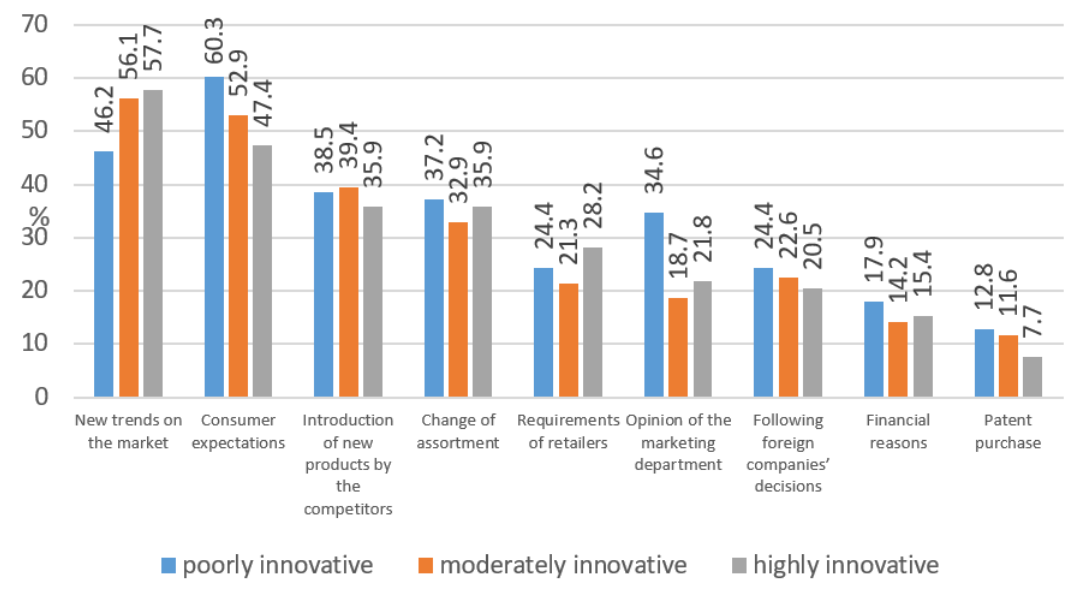

Figure 4. Drivers influencing the introduction of product innovation in bakeries (\% of responses).

In the MCA of factors determining product innovation, three main groups were distinguished. The MCA in Figure 5 and Table 5 illustrates $29.04 \%$ of all inertia (total value of $\mathrm{Chi}^{2}$ statistics $=581.83$ when $p>0.05$ and table $22 \times 22$ ).

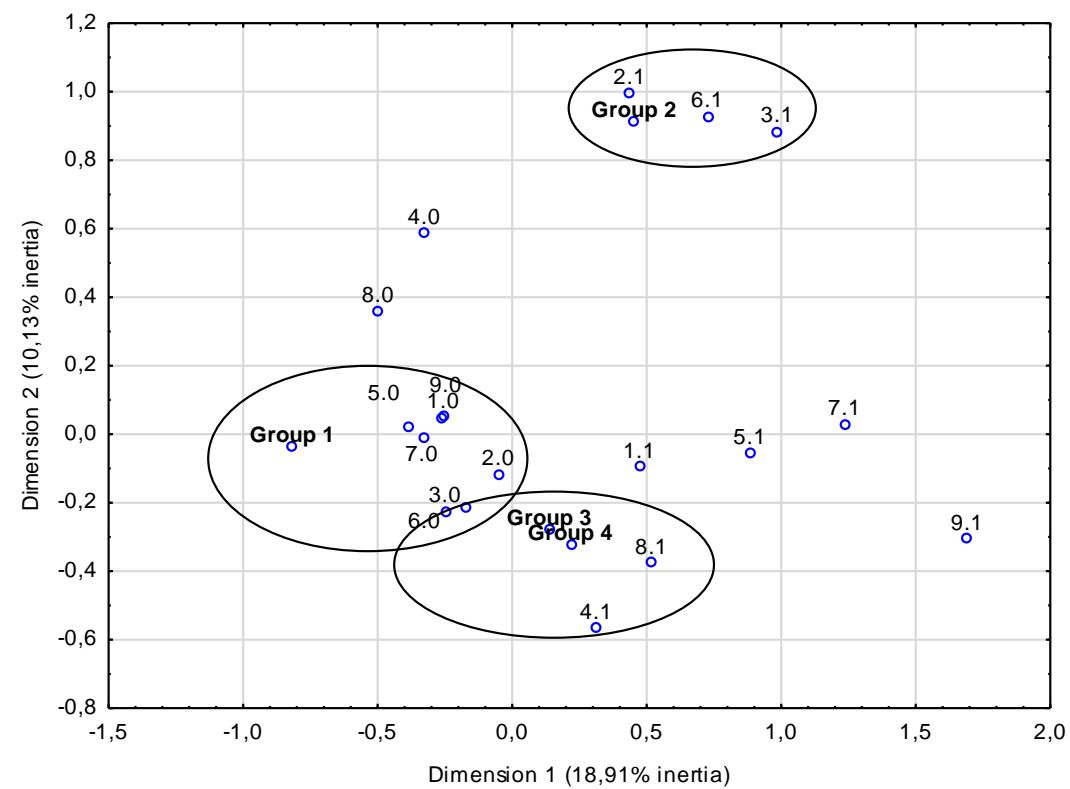

Figure 5. Drivers determining the introduction of product innovation according to MCA results.

Table 5. Explain of Figure 5.

\begin{tabular}{lc}
\hline Code & Mentioned Reasons \\
\hline $1 . X^{*}$ & Introduction of new products by the competitors \\
$2 . X^{*}$ & Patent purchase \\
$3 . X^{*}$ & Opinion of the marketing department \\
$4 . X^{*}$ & New trends on the market \\
$5 . X^{*}$ & Change of assortment \\
$6 . X^{*}$ & Following foreign companies' decisions \\
$7 . X^{*}$ & Requirements of retailers \\
$8 . X^{*}$ & Consumer expectations \\
$9 . X^{*}$ & Financial reasons \\
\hline
\end{tabular}


A lack of factors characterised group 1 (non-innovative companies), and of the 9 factors, only 2 were not in dispute: change of assortment and consumer expectations. This explained the very passive attitude towards product innovation in this group of companies.

Groups 3 and 4 were characterised by similar dimensions of their product innovation factors: consumer expectations (8.1) and new market trends (4.1). Group 2 (poorly innovative companies) was defined in another dimension of established inertia, and the motives for their innovativeness were explained by the purchase of a patent (2.1), opinion of the marketing department (3.1), and following foreign companies' decisions (6.1).

\subsection{Fibre-Enriched Bread as an Example of Product Innovation}

As part of the "Bioproducts" project, an innovative fibre-enriched bread was developed. We asked the representatives of the bakeries participating in the survey how they perceived this innovation to gain a deeper insight into the determinants of product innovation.

First, the perception of four quality attributes of this innovative bread was examined (Figure 6). Respondents from bakeries in groups 2 (poorly innovative) and 3 (moderately innovative) rated two product attributes higher compared to group 4 (highly innovative), namely higher nutritional value and more environmentally friendly production. Bakeries in group 4 rated all the characteristics lower, and the averages ranging from 3.4 to 3.8 showed that they did not have a definite opinion about the advantages of the evaluated product.

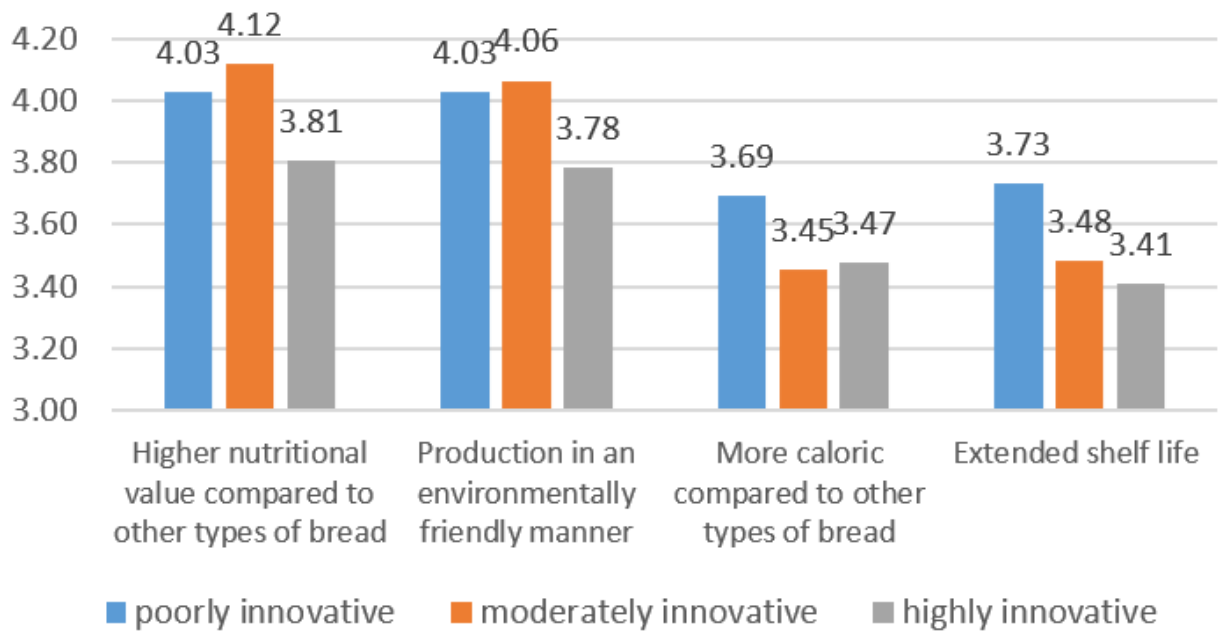

Figure 6. Perception of fibre-enriched bread according to the mean score on a 5-point Likert scale (from 1-totally disagree to 5-totally agree).

Second, the factors that may influence the decision to introduce a product innovation consisting of enriching bread with dietary fibre were examined (Figure 7). The most often indicated answer concerns the necessity to rebuild the raw material supply chain, which was crucial in the case of poorly and moderately innovative companies (64\% of responses in each group). This factor was not so important in the case of bakeries in group 4 (45\%). The second most frequently mentioned driver was changes in production technology, which noticed high relevance in the case of group $4(63 \%)$ and group $3(62 \%)$. In the group of poorly innovative companies, more responses than in the other groups concerned the need for changes in sales organisation (47\%) and in marketing activities (32\%). All groups, however, in a similar percentage (42-45\%) pointed to the need for changes in consumer awareness. 


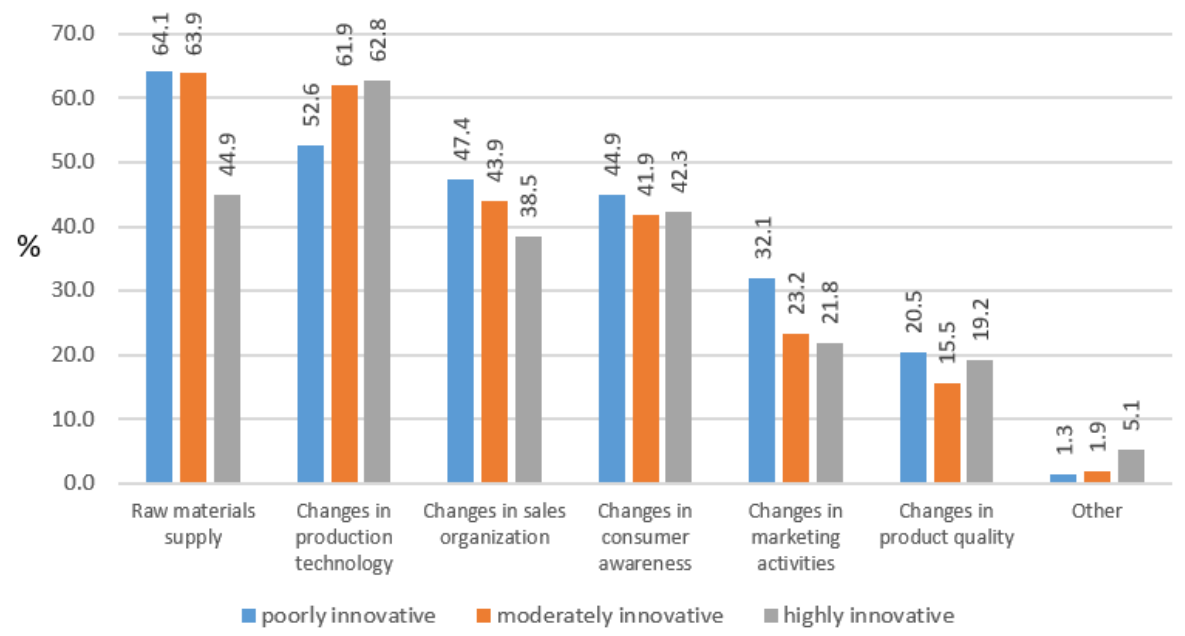

Figure 7. Factors influencing the decision to introduce innovative bread enriched with fibre (\% of responses).

According to the results of MCA on the factors influencing the decision to introduce an innovative fibre-enriched bread (Figure 8 and Table 6), the companies in groups 3 and 4 , as in the previous analysis, were very similar, defined in the same dimensions. The MCA illustrates $30.90 \%$ of all inertia (total value of $\mathrm{Chi}^{2}$ statistics $=554.19$ when $p>0.05$ and table $18 \times 18$ ).

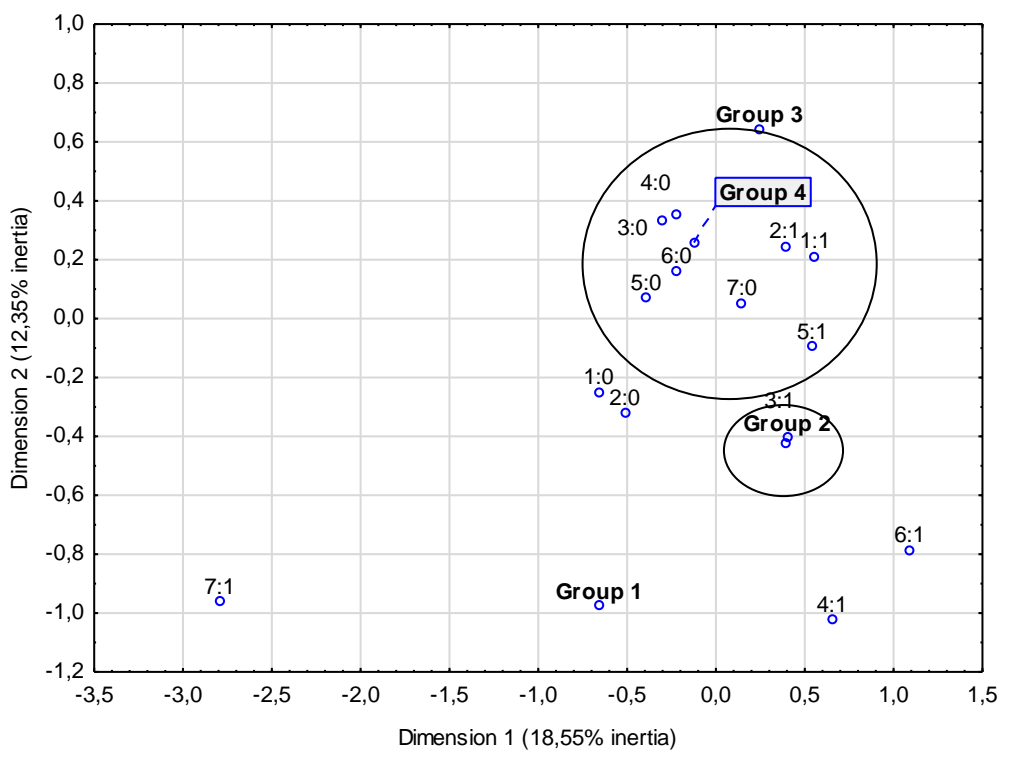

Figure 8. Factors that could influence the decision to introduce innovative fibre-enriched bread according to MCA results.

Table 6. Explain of Figure 8.

\begin{tabular}{lc}
\hline Code & Listed factors \\
\hline $1 . X^{*}$ & Raw materials supply \\
$2 . X^{*}$ & Changes in production technology \\
$3 . X^{*}$ & Changes in sales organisation \\
$4 . X^{*}$ & Changes in marketing activities \\
$5 . X^{*}$ & Changes in consumer awareness \\
$6 . X^{*}$ & Changes in product quality \\
$7 . X^{*}$ & Other \\
\hline
\end{tabular}


Highly innovative companies (Group 4) introduced innovative bread with the addition of fibre depending on changes in production technology (2.1) and raw material supply (1.1). Changes in sales organisation (3.0), marketing activities (4.0), and product quality (6.0) were not considered necessary. An ambiguous response regarding the description of this dimension emerged to changes in consumer awareness (5.0 and 5.1). For moderately innovative companies (group 3), the dimensional similarity established was close to group 4.

More diverse answers were given in Group 2 (poorly innovative companies), where the main criterion was changes in sales organisation. Group 1 of non-innovative companies was not explained by any characteristic.

\section{Discussion}

The study aimed to examine the drivers and types of sustainable product innovations in bakeries with special attention given to fibre-enriched bread. The study was conducted on a sample of bakeries, representing each of the four company sizes: micro, small, medium, and large. Fibre-enriched bread was adopted as a product suitable for sustainable consumption patterns. It provides people with health benefits, manages by-products from fruit and vegetable processing, and can improve company performance. With the clear trend of decreasing bread consumption among the population of developed countries [74-78], innovation is an important competitive tool. Firstly, it is about maintaining consumer interest in bread consumption by expanding the range of products with increased nutritional value. Second, the use of fibre is a way of reducing food waste and is therefore pro-environmental. Third, it is a response to the growing offer of substitute products, such as matzos, rice, and other cereal waffles, crispbread, etc.

Answering the first research question, it should be indicated that almost one in four bakeries participating in the survey had not introduced new products to the market in the year preceding the survey. We have divided the innovative bakeries into three groups depending on the share of newly introduced products in the total assortment range. The largest number of companies introduced new products, accounting for between $5.8 \%$ and $16.1 \%$ of the total product assortment. Analogous groups of bakeries (78 companies each) introduced from one to several new products to the market (share of new products from $1.3 \%$ to $5.8 \%$ ) and from several to dozens (share of new products from $16.1 \%$ to $69.6 \%$ ). Innovation is increasingly recognised as one of the main determinants of organisational success, high operational efficiency, and survival of a company, regardless of its size and the industry it belongs to [48]. The intensity of innovation processes in the baking sector is higher than the average for Poland as a whole. According to the research carried out by PARP (Polish Agency for Enterprise Development), 30.1\% of companies can be described as innovative, i.e., those that have introduced at least one innovation). The share of innovative companies by company size is $29.2 \%$ among micro-companies, $38.7 \%$ among small companies, $43.3 \%$ among medium companies, and 56.7\% among large companies [79].

By asking the second research question, it was found that the most common innovations were new recipes. This was true for all three groups of bakeries, with more than half of the companies in each group reporting such an innovation. The other types of product innovation were a new product for the company, a new product for the consumer, and new packaging. The results for the bakery sector are consistent with those for the food industry as a whole, particularly for novel innovations in health-promoting foods and beverages, nutraceuticals, technological interventions in fermenter upgrading, thermal and non-thermal food processing, and safe packaging technologies [80]. This determines the basic trends in bread, bakery, and pastry innovations in the categories of Health, Pleasure, and Convenience [11]. The prerequisites of the product innovation process in food companies are complex and multifaceted, since in addition to the mentioned categories of innovation, sensory quality must always be kept in mind. Food must taste, which means considering indulgence, texture, colour, weight, aroma, sweet and savoury, and balanced taste aesthetics (sweet, sour, bitter, salty, and umami) [81]. 
In response to the third research question, new market trends, including the activities of competitors and consumer expectations, are perceived as the main determinants of new product launches. Damanpour and Schneider [82] suggested that innovation is often driven by pressure from the external environment and, in particular, by factors such as competition, deregulation, scarcity of resources, and customer demand. In our study, highly innovative companies were mostly driven to introduce product innovations due to new market trends. For the group of poorly innovative companies, consumer expectations were the main driver. This is consistent with research findings cited in the literature. Companies understand that the success of the product on the market has its origins in consumers minds. Therefore, it is fundamental to satisfy their demands [83]. Several studies confirm that consumers are becoming more interested in innovative food products of high quality and providing health benefits $[84,85]$. In this respect, consumers can be a source of product ideas, and such actions might have a positive effect on company performance [86].

The fourth research question addressed the bakeries' perception of fibre-enriched bread. The study showed that fibre-enriched bread is perceived as a product innovation with health-promoting features and produced in an environmentally friendly way. Other researchers emphasise that there is an increasing demand for products with nutritional added value that promote health and wellness $[11,87]$. According to current recommendations, the daily requirement for dietary fibre is $25-35 \mathrm{~g}$ for adults $(25-32 \mathrm{~g} / \mathrm{d}$ for women and $30-35 \mathrm{~g} / \mathrm{d}$ for men). However, the intake in many countries and population groups is below these levels [56]. Depending on the source of dietary fibre, it can be rich in naturally occurring micronutrients, vitamins, and phytochemicals that may synergistically improve human health [88-90]. It can also be used as a non-caloric bulking agent for partial replacement of flour, fat, or sugar as an enhancer of water and oil retention, thereby reducing the calorific value of the product [91]. However, dietary fibre has been shown to alter certain properties of food products that may not correspond to the sensory attributes of bread quality imagined and expected by consumers. It can modify the textural properties of bread, such as loaf volume, springiness, crumb softness, and loaf firmness [91].

The introduction of new products enriched or fortified with fibre may also reduce food losses, as it is extracted from the waste generated in many food processing industries. This can improve adverse environmental impacts and economic indicators. There is a growing interest and a growing number of technical solutions to recover valuable compounds of functional importance in human nutrition from food processing waste [61,92]. The possibility of utilising food processing by-products for manufacturing various cosmetics, pharmaceuticals, and foods has created an enormous scope for waste reduction and indirect income generation. By-products from the food industry are known to be sources of functional ingredients, such as dietary fibre, minerals, and phytochemicals, among others, which can be used in food production $[93,94]$. Such activities are part of the idea of a circular economy, which is of key importance for achieving sustainable development of the planet.

Nowadays, food companies understand that to stand out from the competition; they have to invest in new products, technologies, or services [48]. The field of food production and processing is changing significantly in response to changing consumer expectations. Food is no longer seen solely in terms of satisfying hunger and providing essential nutrients. The task of today's food industry is to provide products that prevent nutrition-related diseases and improve physical and mental well-being [95]. However, these expectations towards food processing are not confirmed by the highly innovative bakery companies participating in our survey. The lowest scores for the perception of the beneficial properties of the addition of fibre in bread obtained in this group may suggest that they do not have sufficient knowledge of the relationship between nutrition and health or have already introduced product innovations increasing the fibre content of their bakery products (e.g., the addition of grains, seeds, dried fruit, or nuts to the dough).

The final research question focused on the drivers for launching a sustainable innovation in bakeries. The pursuit of innovation and new product development, combined with 
careful market observation and nutritional knowledge of product managers, can contribute to the creation of products that are of interest to both companies and consumers. Bakery producers should better understand what consumers want and have up-to-date knowledge on consumption and health trends. The introduction of functional bread additives is an intensively exploited type of innovation worldwide, and the possibilities concern completely innovative additives, such as mushrooms [96] or seaweed-based ingredients. Consumer trends towards new products include artisan bread varieties, a push towards clean labelling, and new product development in specific segments of the bread market, such as breakfast, premium, and organic. The Polish market witnessed a dynamic development of artisan bakeries following the trend of revitalisation. They bake bread according to traditional recipes and use ingredients that have been forgotten in the times of mass food production. These breads are characterised by a high proportion of whole grain and high quality, without baking enhancers, anti-mould substances, artificial colours and flavours, fructose syrup, or barley malt.

Our findings provide strengths and fill a research gap in sustainable innovation in the baking industry. We have presented new research areas resulting from the implemented "Bioproducts" project, as well as indicated various aspects of an undertaking of product innovation in the sector of bread production in Poland. Each of them requires further in-depth research in particular segments of the bread market. This research also has some limitations. They are related, on the one hand, to the conservative perception of this product category and, on the other hand, to the high dispersion of companies, as the bakery sector is the most fragmented industry in Polish food processing and is dominated by micro entities ( $99 \%$ of the number of entities. Companies operate in local markets of different sizes, including small, undemanding, and non-innovative markets and markets in large cities where consumers are more demanding and innovative. Significant limitations also resulted from the reluctance of entities to participate in the survey, which largely determined the sample size.

\section{Conclusions}

The study presented in the paper concerned the issues of product innovation in the Polish baking sector. Most companies (more than three-quarters) participating in the survey declared the introduction of sustainable product innovations, with varying intensity depending on the size of the company.

Recipe modifications and new recipes to keep up with market trends and meet consumer expectations were the main drivers for undertaking innovation processes in the surveyed bakeries. Experts from the bakery industry [97,98] suggest that the ongoing pandemic has caused significant changes in lifestyles and consumption habits, which were also strongly reflected in the market for bakery products. The changes have been linked to increased work flexibility, relocation closer to nature, translating into a search for new product categories to enrich the eating experience at home. Consumer awareness of the quality of what they eat has increased, resulting in a greater willingness to buy better quality products, including those in the indulgence category. Consumers increasingly see food as an opportunity to experience flavours and textures and are particularly responsive to products that are positioned as natural and healthy. Increased health awareness will be a strong driver of the trend to provide the market with baked goods with increased nutritional value, high in fibre, protein, and other plant-based additives.

Bakeries that respond to these trends and undertake sustainable innovations at the same time work towards their competitiveness. So, this study opens the field for further research in the domain of sustainable innovation in the bakery industry in Poland. The key question is the profitability of innovation in this sector. An interesting aspect is also the deepening of knowledge about the impact of factors characterising companies on innovation launching. It would also be interesting to gain a more in-depth insight into other innovative activities undertaken by bakery companies. 
Author Contributions: Conceptualisation: M.K. and H.G.-W.; methodology: M.K. and H.G.-W.; validation: H.G.-W.; visualisation: M.K. and M.M.-S.; formal analysis: M.M.-S. and M.K.; data analysis: M.K., M.M.-S., M.C. and J.S.; supervision H.G.-W. and K.R.; writing-original draft preparation: M.K., H.G.-W., K.R. and J.S.; writing-review and editing: S.Ż.-B., R.Z., B.K., M.W. and K.R. All authors have read and agreed to the published version of the manuscript.

Funding: Project No. POIG.01.03.01-14-041/12 “'Bioproducts', innovative technologies of pro-health bakery products and pasta with reduced caloric value". It was co-financed by the European Regional Development Fund under the Innovative Economy Operational Programme 2007-2013. The Article Processing Charge was financed by the Polish Ministry of Science and Higher Education within funds of Institute of Human Nutrition, Warsaw University of Life Sciences (WULS) for scientific research.

Institutional Review Board Statement: Not applicable.

Informed Consent Statement: Not applicable.

Data Availability Statement: Data are available at the Department of Food Market and Consumption research in the Institute of Human Nutrition Sciences, Warsaw University of Life Sciences, in Poland.

Acknowledgments: This study is part of Project No. POIG.01.03.01-14-041/12 "'Bioproducts', innovative technologies of pro-health bakery products and pasta with reduced caloric value". It was co-financed by the European Regional Development Fund under the Innovative Economy Operational Programme 2007-2013.

Conflicts of Interest: The authors declare no conflict of interest.

\section{References}

1. Kuncoro, W.; Suriani, W.O. Achieving sustainable competitive advantage through product innovation and market driving. Asia Pacific. Manag. Rev. 2018, 23, 186-192. [CrossRef]

2. Handen, J.S. Redefining innovation. In Re-Inventing Drug Development; CRC Press: Boca Raton, FL, USA, $2014 ;$ pp. 1-11. [CrossRef]

3. Mohd Zawawi, N.F.; Abd Wahab, S.; Al-Mamun, A.; Sofian Yaacob, A.; Kumar AL Samy, N.; Ali Fazal, S. Defining the Concept of Innovation and Firm Innovativeness: A Critical Analysis from Resorce-Based View Perspective. Int. J. Bus. Manag. 2016, 11, 87. [CrossRef]

4. Wainwright, J.T. The Nature and Importance of Innovation. In Innovation, Intellectual Property, and Economic Growth; Princeton University Press: Princeton, NJ, USA, 2009.

5. Dadfar, H.; Dahlgaard, J.J.; Brege, S.; Alamirhoor, A. Linkage between organisational innovation capability, product platform development and performance: The case of pharmaceutical small and medium enterprises in Iran. Total Qual. Manag. Bus. Excell. 2013, 24, 819-834. [CrossRef]

6. Hurley, R.F.; Hult, G.T.M.; Knight, G.A. Innovativeness and capacity to innovate in a complexity of firm-level relationships: A response to Woodside (2004). Ind. Mark. Manag. 2005, 34, 281-283. [CrossRef]

7. Woodside, A.G. Firm orientations, innovativeness, and business performance: Advancing a system dynamics view following a comment on Hult, Hurley, and Knight's 2004 study. Ind. Mark. Manag. 2005, 34, 275-279. [CrossRef]

8. Weerawardena, J. The role of marketing capability in innovation-based competitive strategy. J. Strateg. Mark. 2003, 11, 15-35. [CrossRef]

9. Tsai, K.H.; Yang, S.Y. Firm innovativeness and business performance: The joint moderating effects of market turbulence and competition. Ind. Mark. Manag. 2013, 42, 1279-1294. [CrossRef]

10. Lisboa, A.; Skarmeas, D.; Lages, C. Entrepreneurial orientation, exploitative and explorative capabilities, and performance outcomes in export markets: A resource-based approach. Ind. Mark. Manag. 2011, 40, 1274-1284. [CrossRef]

11. Martínez-Monzó, J.; García-Segovia, P.; Albors-Garrigos, J. Trends and innovations in bread, bakery, and pastry. J. Culin. Sci. Technol. 2013, 11, 56-65. [CrossRef]

12. Ciurzyńska, A.; Cieśluk, P.; Barwińska, M.; Marczak, W.; Ordyniak, A.; Lenart, A.; Janowicz, M. Eating Habits and Sustainable Food Production in the Development of Innovative "Healthy" Snacks (Running Title: Innovative and "Healthy" Snacks). Sustainability 2019, 11, 2800. [CrossRef]

13. Feili, R. Physical and Sensory Analysis of High Fiber Bread Incorporated with Jackfruit Rind Flour. Food Sci. Technol. 2013, 1, 30-36. [CrossRef]

14. López, E.P.; Goldner, M.C. Influence of storage time for the acceptability of bread formulated with lupine protein isolate and added brea gum. LWT-Food Sci. Technol. 2015, 64, 1171-1178. [CrossRef]

15. Ben Jeddou, K.; Bouaziz, F.; Zouari-Ellouzi, S.; Chaari, F.; Ellouz-Chaabouni, S.; Ellouz-Ghorbel, R.; Nouri-Ellouz, O. Improvement of texture and sensory properties of cakes by addition of potato peel powder with high level of dietary fiber and protein. Food Chem. 2017, 217, 668-677. [CrossRef] [PubMed] 
16. Torbica, A.; Škrobot, D.; Janić Hajnal, E.; Belović, M.; Zhang, N. Sensory and physico-chemical properties of wholegrain wheat bread prepared with selected food by-products. LWT 2019, 114, 108414. [CrossRef]

17. Pratap Singh, A.; Mandal, R.; Shojaei, M.; Singh, A.; Kowalczewski, P.Ł.; Ligaj, M.; Pawlicz, J.; Jarzębski, M. Novel Drying Methods for Sustainable Upcycling of Brewers' Spent Grains as a Plant Protein Source. Sustainability 2020, 12, 3660. [CrossRef]

18. Oksanen, K.; Hautamäki, A. Sustainable Innovation: A Competitive Advantage for Innovation Ecosystems. Technol. Innov. Manag. Rev. 2015, 5, 24-30. [CrossRef]

19. Jaksic, M.L. Sustainable Innovation of Technology and Business Models: Rethinking Business Strategy. South-East. Eur. J. Econ. 2016, 14, 127-139.

20. Lorek, P. Sustainable innovation as an important factor of firm development. Ekon. Środowisko 2018, 1, 32-40.

21. Kogabayev, T.; Maziliauskas, A. The definition and classification of innovation. Holist. J. Bus. Public Adm. 2017, 8, 59-72. [CrossRef]

22. Drucker, P. Innovation and Entrepreneurship; Harper \& Row, Business \& Economics: Manhattan, NY, USA, 1985.

23. Von Stamm, B. Managing Innovation, Design And Creativity; J. Wiley: Hoboken, NJ, USA, 2003; ISBN 9780470847084.

24. Abujarad, I.; Yusof, N. Innovation creation and innovation adoption: A proposed matrix towards a better understanding. Int. J. Organ. Innov. 2010, 3, 303-324.

25. Akgun, A.; Kocoglu, I.; Keskin, H.; Ince, H.; Imamoglu, S. The Relationship Between Intellectual Capital, Innovation and Competitive Advantage. In Proceedings of the 5th European Conference on Innovation and Entrepreneurship, Athens, Greece, 16-17 September 2010.

26. Slater, S.F. The challenge of sustaining competitive advantage. Ind. Mark. Manag. 1996, 25, 79-86. [CrossRef]

27. Hult, G.T.M.; Hurley, R.F.; Knight, G.A. Innovativeness: Its antecedents and impact on business performance. Ind. Mark. Manag. 2004, 33, 429-438. [CrossRef]

28. Tuominen, M.; Hyvönen, S. Organizational innovation capability: A driver for competitive superiority in marketing channels. Int. Rev. Retail. Distrib. Consum. Res. 2004, 14, 277-293. [CrossRef]

29. Vanhaverbeke, W.; Peeters, N. Embracing Innovation as Strategy: Corporate Venturing, Competence Building and Corporate Strategy Making. Creat. Innov. Manag. 2005, 14, 246-257. [CrossRef]

30. Wang, W.-C.; Lin, C.-H.; Chu, Y.-C. Types of Competitive Advantage and Analysis. Int. J. Bus. Manag. 2011, 6, 100-104. [CrossRef]

31. Grant, R.M. The Resource-Based Theory of Competitive Advantage: Implications for Strategy Formulation. Calif. Manag. Rev. 1991, 33, 114-135. [CrossRef]

32. Švárová, M.; Vrchota, J. Influence of Competitive Advantage on Formulation Business Strategy. Procedia Econ. Financ. 2014, 12, 687-694. [CrossRef]

33. Barney, J.B. Firm Resources and Sustained Competitive Advantage. J. Manag. 1991, 17, 99-120. [CrossRef]

34. Śmigielska, G. Creation of competitive advantage in retail trade based on M.Porter theory (in Polish) Kształtowanie przewagi konkurencyjnej w handlu detalicznym w świetle teorii M. Portera. Zesz. Nauk. Akad. Ekon. W Krakowie 2004, 664, 57-69.

35. Sweezy, P.M. Professor Schumpeter's Theory of Innovation. Rev. Econ. Stat. 1943, 25, 93. [CrossRef]

36. Cantner, U.; Gaffard, J.L.; Nesta, L. Schumpeterian perspectives on innovation, competition, and growth. J. Evol. Econ. 2008, 18, 291-293. [CrossRef]

37. Heertje, A. Schumpeter on the Economics of Innovation and the Development of Capitalism; Edward Elgar: Cheltenham, UK, 2006; 142p, ISBN 1-84542-445-X.

38. Drejer, I. Identifying innovation in surveys of services: A Schumpeterian perspective. Res. Policy 2004, 33, 551-562. [CrossRef]

39. Malerba, F.; Orsenigo, L. Schumpeterian patterns of innovation. Camb. J. Econ. 1995, 19, 47-65. [CrossRef]

40. Morton, K.; Schwartz, N. Market Structure and Innovation; Press Syndicate of the University of Cambridge: Cambridge, UK, 1982.

41. Kenney, M. Schumpeterian innovation and entrepreneurs in capitalism: A case study of the U.S. biotechnology industry. Res. Policy 1986, 15, 21-31. [CrossRef]

42. Autio, E.; Kenney, M.; Mustar, P.; Siegel, D.; Wright, M. Entrepreneurial innovation: The importance of context. Res. Policy 2014, 43, 1097-1108. [CrossRef]

43. Becker, M.C.; Knudsen, T. Schumpeter and the Organization of Entrepreneurship. In The Oxford Handbook of Sociology and Organization Studies: Classical Foundations; Oxford University Press: Oxford, UK, 2009; ISBN 9780191577352.

44. Godin, B. In the shadow of Schumpeter: W. Rupert Maclaurin and the study of technological innovation. Minerva 2008, 46, 343-360. [CrossRef]

45. Rowley, J.; Baregheh, A.; Sambrook, S. Towards an innovation-type mapping tool. Manag. Decis. 2011, 49, 73-86. [CrossRef]

46. OECD/Eurostat. Oslo Manual 2018: Guidelines for Collecting, Reporting and Using Data on Innovation, 4th ed.; OECD/Eurostat: Paris, France, 2018; ISBN 9789264304550.

47. Jones, P.J.; Jew, S. Functional food development: Concept to reality. Trends Food Sci. Technol. 2007, 18, 387-390. [CrossRef]

48. Bigliardi, B.; Galati, F. Innovation trends in the food industry: The case of functional foods. Trends Food Sci. Technol. 2013, 31, 118-129. [CrossRef]

49. Horvat, A.; Granato, G.; Fogliano, V.; Luning, P.A. Understanding consumer data use in new product development and the product life cycle in European food firms-An empirical study. Food Qual. Prefer. 2019, 76, 20-32. [CrossRef]

50. 2030 Global Food and Drink Trends. Available online: https://www.mintel.com (accessed on 20 December 2021). 
51. Sajdakowska, M.; Królak, M.; Zychowicz, W.; Jezewska-Zychowicz, M. Acceptance of food technologies, perceived values and consumers' expectations towards bread. A survey among Polish sample. Sustainability 2018, 10, 1281. [CrossRef]

52. Kaur, K.D.; Jha, A.; Sabikhi, L.; Singh, A.K. Significance of coarse cereals in health and nutrition: A review. J. Food Sci. Technol. 2014, 51, 1429-1441. [CrossRef] [PubMed]

53. Velázquez-López, L.; Muñoz-Torres, A.V.; García-Peña, C.; López-Alarcón, M.; Islas-Andrade, S.; Escobedo-De La Peña, J. Fiber in diet is associated with improvement of glycated hemoglobin and lipid profile in mexican patients with type 2 diabetes. J. Diabetes Res. 2016, 2016, 2980406. [CrossRef] [PubMed]

54. Veronese, N.; Solmi, M.; Caruso, M.G.; Giannelli, G.; Osella, A.R.; Evangelou, E.; Maggi, S.; Fontana, L.; Stubbs, B.; Tzoulaki, I. Dietary fiber and health outcomes: An umbrella review of systematic reviews and meta-analyses. Am. J. Clin. Nutr. 2018, 107, 436-444. [CrossRef] [PubMed]

55. Li, Y.O.; Andrew, R. Komarek Dietary fibre basics: Health, nutrition, analysis, and applications. Food Qual. Saf. 2017, 1, 47-59. [CrossRef]

56. Stephen, A.M.; Champ, M.M.J.; Cloran, S.J.; Fleith, M.; Van Lieshout, L.; Mejborn, H.; Burley, V.J. Dietary fibre in Europe: Current state of knowledge on definitions, sources, recommendations, intakes and relationships to health. Nutr. Res. Rev. 2017, 30, 149-190. [CrossRef]

57. Antonić, B.; Jančíková, S.; Dordević, D.; Tremlová, B. Grape pomace valorization: A systematic review and meta-analysis. Foods 2020, 9, 1637. [CrossRef]

58. Moons, I.; Barbarossa, C.; De Pelsmacker, P. The Determinants of the Adoption Intention of Eco-friendly Functional Food in Different Market Segments. Ecol. Econ. 2018, 151, 151-161. [CrossRef]

59. Baixauli, R.; Sanz, T.; Salvador, A.; Fiszman, S.M. Muffins with resistant starch: Baking performance in relation to the rheological properties of the batter. J. Cereal Sci. 2008, 47, 502-509. [CrossRef]

60. Heo, Y.; Kim, M.J.; Lee, J.W.; Moon, B.K. Muffins enriched with dietary fiber from kimchi by-product: Baking properties, physical-chemical properties, and consumer acceptance. Food Sci. Nutr. 2019, 7, 1778-1785. [CrossRef]

61. Alava, C.; Verdú, S.; Barat, J.M.; Grau, R. Enrichment of chips with fibre from a tiger-nut (Cyperus esculentus) milk co-product at 'source of fibre foods' and 'high fibre content foods' levels: Impact on processing, physico-chemical and sensory properties. Int. J. Food Sci. Technol. 2019, 54, 908-915. [CrossRef]

62. Borczak, B.; Sikora, E.; Sikora, M.; Rosell, C.M.; Collar, C. Glycaemic response to frozen stored wheat rolls enriched with inulin and oat fibre. J. Cereal Sci. 2012, 56, 576-580. [CrossRef]

63. Martin, C.; Chiron, H.; Issanchou, S. Impact of dietary fiber enrichment on the sensory characteristics and acceptance of French baguettes. J. Food Qual. 2013, 36, 324-333. [CrossRef]

64. Królak, M.; Jeżewska-Zychowicz, M.; Sajdakowska, M.; Gębski, J. Does perception of dietary fiber mediate the impact of nutrition knowledge on eating fiber-rich bread? Nutrients 2017, 9, 1255. [CrossRef] [PubMed]

65. Zychowicz, M.J.; Królak, M. The Choice of Bread: The Association between Consumers' Awareness of Dietary Fiber and Declared Intentions to Eat. Nutrients 2020, 12, 360. [CrossRef] [PubMed]

66. The Civil Law. Dz.U. 2018 poz. 1025; Polish Government: Warsaw, Poland, 2018; pp. 1-35.

67. Abdi, H.; Valentin, D. Multiple correspondence analysis. In Multiple Correspondence Analysis for The Social Sciences; Routledge: London, UK, 2018; pp. 31-55. [CrossRef]

68. Khangar, N.V.; Kamalja, K.K. Multiple Correspondence Analysis and its applications. Electron. J. Appl. Stat. Anal. 2017, 10, 432-462. [CrossRef]

69. Carroll, J.D.; Green, P.E.; Schaffer, C.M. Interpoint Distance Comparisons in Correspondence Analysis. J. Mark. Res. 1986, 23, 271-280. [CrossRef]

70. Carroll, J.D.; Green, P.E. An INDSCAL-Based Approach to Multiple Correspondence Analysis. J. Mark. Res. 1988, 25, 193-203. [CrossRef]

71. Hoffman, D.L.; Franke, G.R. Correspondence Analysis: Graphical Representation of Categorical Data in Marketing Research. J. Mark. Res. 1986, 23, 213-227. [CrossRef]

72. Kaciak, E.; Louviere, J. Multiple Correspondence Analysis of Multiple Choice Experiment Data. J. Mark. Res. 1990, 27, 455-465. [CrossRef]

73. Bayram, N. An Application about the problems of women in the labour force with multiple correspondence analysis. Dokuz Eylül Üniversitesi Sos. Bilimler Enstitüsü Derg. 2003, 5, 1-11.

74. Eglite, A.; Kunkulberga, D. Bread Choice and Consumption Trends. In Proceedings of the Baltic Conference on Food Science and Technology FOODBALT “Food for Consumer Well-Being”, Jelgava, Latvia, 27-28 April 2017. [CrossRef]

75. Żakowska-Biemans, S.; Sajdakowska, M.; Jeżewska-Zychowicz, M. Consumers towards changes in the bread market: Their differentiation and determinants of choice (in Polish) Konsumenci wobec zmian na rynku pieczywa: Ich zróżnicowanie i uwarunkowania wyboru. Handel Wewn. 2018, 64, 424-437.

76. Sajdakowska, M.; Gębski, J.; Żakowska-Biemans, S.; Jeżewska-Zychowicz, M. Willingness to eat bread with health benefits: Habits, taste and health in bread choice. Public Health 2019, 167, 78-87. [CrossRef] [PubMed]

77. Bread from Europe IChafea. Available online: https://ec.europa.eu/chafea/agri/en/campaigns/bread-europe (accessed on 20 December 2021). 
78. Kowrygo, B.; Górska-Warsewicz, H.; Berger, S. Evaluation of eating patterns with different methods: The Polish experience. Appetite 1999, 32, 86-92. [CrossRef]

79. Monitoring Innowacyjności Polskich Przedsiębiorstw-Wyniki III Edycji Badania-2020-PARP-Centrum Rozwoju MŚP. Available online: https:/ / www.parp.gov.pl/component/publications/publication/monitoring-innowacyjnosci-polskich-przedsiebiorstwwyniki-iii-edycji-badania-2020 (accessed on 16 August 2021).

80. Sahu, L.; Panda, S.K. Innovative Technologies and Implications in Fermented Food and Beverage Industries: An Overview. In Innovations in Technologies for Fermented Food and Beverage Industries; Springer: Cham, Switzerland, 2018; pp. 1-23. [CrossRef]

81. New Flavour Ideas from Bakery Trends and Innovation the Product. Available online: https://bakingbusiness.com.au/bakerytrends-innovation/ (accessed on 3 November 2021).

82. Damanpour, F.; Schneider, M. Characteristics of innovation and innovation adoption in public organizations: Assessing the role of managers. J. Public Adm. Res. Theory 2009, 19, 495-522. [CrossRef]

83. Bleiel, J. Functional foods from the perspective of the consumer: How to make it a success? Int. Dairy J. 2010, 20, 303-306. [CrossRef]

84. Barrena, R.; García, T.; Sánchez, M. Analysis of personal and cultural values as key determinants of novel food acceptance. Application to an ethnic product. Appetite 2015, 87, 205-214. [CrossRef]

85. Bittner, J.V.; Kulesz, M.M. Health promotion messages: The role of social presence for food choices. Appetite 2015, 87, 336-343. [CrossRef]

86. Zaborek, P.; Mazur, J. Enabling value co-creation with consumers as a driver of business performance: A dual perspective of Polish manufacturing and service SMEs. J. Bus. Res. 2019, 104, 541-551. [CrossRef]

87. Bimbo, F.; Bonanno, A.; Nocella, G.; Viscecchia, R.; Nardone, G.; De Devitiis, B.; Carlucci, D. Consumers' acceptance and preferences for nutrition-modified and functional dairy products: A systematic review. Appetite 2017, 113, 141-154. [CrossRef]

88. Dahl, W.J.; Stewart, M.L. Position of the Academy of Nutrition and Dietetics: Health Implications of Dietary Fiber. J. Acad. Nutr. Diet. 2015, 115, 1861-1870. [CrossRef]

89. Shivakoti, R.; Tuddenham, S.; Caulfield, L.E.; Murphy, C.; Robinson, C.; Ravel, J.; Ghanem, K.G.; Brotman, R.M. Dietary macronutrient intake and molecular-bacterial vaginosis: Role of fiber. Clin. Nutr. 2020, 39, 3066-3071. [CrossRef] [PubMed]

90. MacArtain, P.; Gill, C.I.R.; Brooks, M.; Campbell, R.; Rowland, I.R. Nutritional Value of Edible Seaweeds. Nutr. Rev. 2008, 65, 535-543. [CrossRef]

91. Elleuch, M.; Bedigian, D.; Roiseux, O.; Besbes, S.; Blecker, C.; Attia, H. Dietary fibre and fibre-rich by-products of food processing: Characterisation, technological functionality and commercial applications: A review. Food Chem. 2011, 124, 411-421. [CrossRef]

92. Sáyago-Ayerdi, S.G.; Velázquez-López, C.; Montalvo-González, E.; Goñi, I. By-product from decoction process of Hibiscus sabdariffa L. calyces as a source of polyphenols and dietary fiber. J. Sci. Food Agric. 2014, 94, 898-904. [CrossRef] [PubMed]

93. Martins, Z.E.; Pinho, O.; Ferreira, I.M.P.L.V.O. Food industry by-products used as functional ingredients of bakery products. Trends Food Sci. Technol. 2017, 67, 106-128. [CrossRef]

94. Sharma, S.K.; Bansal, S.; Mangal, M.; Dixit, A.K.; Gupta, R.K.; Mangal, A.K. Utilization of food processing by-products as dietary, functional, and novel fiber: A review. Crit. Rev. Food Sci. Nutr. 2016, 56, 1647-1661. [CrossRef]

95. Menrad, K. Market and marketing of functional food in Europe. J. Food Eng. 2003, 56, 181-188. [CrossRef]

96. Yuan, B.; Zhao, L.; Yang, W.; McClements, D.J.; Hu, Q. Enrichment of Bread with Nutraceutical-Rich Mushrooms: Impact of Auricularia auricula (Mushroom) Flour Upon Quality Attributes of Wheat Dough and Bread. J. Food Sci. 2017, 82, 2041-2050. [CrossRef]

97. Three Factors That Will Shape the Bakery of the Future-Commercial Baking. Available online: https://commercialbaking.com/ three-factors-that-will-shape-the-bakery-of-the-future/ (accessed on 27 December 2021).

98. Top 6 Global Industrial Bakery Trends. 2021. Available online: https://www.freyabadi.com/en/blog/top-6-global-industrialbakery-trends-2021 (accessed on 27 December 2021). 